\title{
Brownian Dynamics Simulation of FENE Dumbbell Model for Dilute Polymer Solutions in Extensional Flow: Effect of Distribution of FENE Parameter and Relaxation Time
}

\author{
Kunji CHIBA*, Kanji TeraOKA**, Yuji IOKITO**, and Kiyoji NAKAMURA** \\ *Faculty of Education, Shiga University, Otsu, Shiga \\ ** Department of Mechanophysics Engineering, Graduate School of Engineering, \\ Osaka University, Suita, Osaka
}

\begin{abstract}
Brownian dynamics (BD) simulations of the steady and transient rheological behaviors of FENE dumbbell model for dilute polymer solutions in uniaxial extensional flow are reported. The simulations include examination of the effects of distributions of maximum allowable extension (FENE parameter $b$ ) and of relaxation time parameter $\alpha$.

Stretch-thickening and strain-hardening behaviors, which can be often observed in polymer solutions, are confirmed in the simulations either with or without the distribution of $b$ or $\alpha$. However, overshoot phenomenon in a start-up extensional flow can never be observed unlike the situation in a start-up shear flow. Curves of transient extensional viscosity vs. strain clearly show that the extensional viscosity is independent of the stretch rate in the regime of $\alpha \lambda_{0} \dot{\varepsilon}>1 \sim 2$ where polymer solutions exhibit significant strain-hardening.

Furthermore, it is found that the distribution of $b$ has little influence on extensional flow properties while the distribution of $\alpha$ can affect both the steady and transient extensional flow properties under the distribution condition used in the simulations. BD simulation can precisely predict the extensional viscosity even in the low stretch rate region.

Key Words: Brownian dynamics simulation / FENE dumbbell model / Extensional flow properties / Distribution of maximum extension / Distribution of relaxation time.
\end{abstract}

\section{FENE dumbbellモデルを用いた希薄高分子溶液の伸長流動特性の ブラウン運動学シミュレーション： FENEパラメータおよび緩和時間の分布の影響}

\author{
千葉 訓司 ${ }^{* 1}$, 寺岡 寛二*2, 五百旗頭祐二*2, 中村喜代次 ${ }^{* 2}$
}

(原稿受理 : 1998年8月10日)

1. まえがき

前報1)の「1まえがき」で, 連続体的手法に代わって分子 モデルを用いた高分子液体のレオロジー特性に関する従来の 研究については詳細に述べている. 本報では, 前報のせん断 流動特性に関する報告に引き続いて伸長流動特性について BD simulationにより得られた結果を報告する. 乥こで, 分子 モデルを用いた従来の伸長流動特性の研究について簡単に概 説する.

最も単純なHookean dumbbellモデルを用いると，伸長流 れでは有限の伸長速度でdumbbellの長さが無限大になるた め，伸長粘度は無限に増大する2) . 一方, Hookean springの 代わりにFENE (Finitely Extensible Nonlinear Elastic) spring ${ }^{3)}$

\footnotetext{
*1滋賀大学教育学部

干 520-0862 大津市平津2-5-1

*2 大阪大学大学院工学研究科機械物理工学専攻

于565-0871 吹田市山田丘2-1
}

を用いると, Hookean springモデルの欠点の幾つかが解消さ れる.第一の改良点は八゙ネの伸びが一定値に抑えられること であり，このため，有限の伸長粘度が得られる2゙,4)。

更に, dumbbellモデルより害際の分子に近いモデルとして chainモデル (FENE chain) が提案された。しかし, 実用的 には光の複雑さを低減するための近似としてPeterlin ${ }^{5)}$ が提 案したFENE-P chainが用いられている . FENE-P chainの場合， 応力を計算するために連立して解かなければならない方程式 の数が多いことが欠点である. 弚こで, 支配方程式の数を減 らす工夫かWedgewoodらのによりなされ (FENE-PM chain) FENE-PM chainを用いて定常伸長流動特性を計算し，FENEP chainの結果とほぼ一致することを確かめている .

一方，BD simulationによる伸長流動特性の研究としては 次のものがある . van den Brule ( chainおよびFENE-PM chainについて定常ならびに過渡的伸 長流動特性を計算した。FENE chainと比較してFENE-P 
chainとFENE-PM chainの場合, スタートアップ流れにおいて 定常值に到達する直前の伸長粘度の変化に幾分違いか認めら れるが, 伸長特性を十分に表すことができることを示した . FetskoとCummings ${ }^{8)}$ ( ならびに過渡的伸長流動特性を計算し, 流体力学的相互作用, 排除体積, chainの長さの影響を調べた . chainの長さが短い 場合には流体力学的相互作用およひ排除体積が定常流動特性 に大きな影響を及ぼすことを明らかにした．更に，Herrchen とÖttinger') は単純伸長流動特性に関して, BD simulationに より求めたFENE dumbbellの結果と構成式から計算した FENE-P dumbbellおよびFENE-CR (Chilcott-Rallison version ${ }^{10)}$ ) dumbbellの結果を比較した . 定常流動特性はほぼ一致するが， 過渡的流動特性には大きな差が見られることを報告して いる。

上述した従来の研究では, 分子量分布がない場合の高分子 溶液のレオロジー特性に関する研究が大部分である．ところ が, 実際の高分子溶液では分子量が分布しており, これがレ オロジ一特性に大きく影響することが知られている．关こで， 本研究は, FENE dumbbellの希薄懸濁液でモデル化した希薄 高分子溶液を対象として, 光のレオロジー特性に及ぼす分子 の最大伸長長さの分布ならびに緩和時間の分布の影響につい て調べることを目的としている．

ここで対象にしたレオロジー特性は, 単純伸長流れにおけ る定常流動特性とスタートアップ流動特性である．これらの 特性をBD simulationにより求め, 分子の最大伸長長さおよび 緩和時間が分布しない場合の結果と比較する . 更に, 計算に より得られる分子の長さおよび配列の変化から高分子液体特 有のレオロジー特性の発生メカニズムについて考える .

以上の伸長特性の数值解析に対して, 最近では, 従来測定 不可能であった高分子溶液の過渡的伸長粘度がfilament stretching rheometer を用いて盛んに測定されている11 15) た, 弚の流動過程の数值解析 ${ }^{16 \sim 18)}$ も行われている.これに より, せん断流れと伸長流れが同時に発生する場合の粘弾性 流体特有の複杂隹な゙流れのメカニズムの解明が一層期待される . 本報では, これらの測定結果との比較も一部行うことにする.

\section{2. レオロジー特性の計算法}

ここでは, (a) 定常伸長流動特性, (b) スタートアップ伸長 流動特性 , について計算を行う.

基礎理論，BD simulationの方法ならびに計算手順について (は前報1)で詳細に述べているのでここでは省略する．また， 前報同樣流体力学的相互作用の影響については考えない .

本報に関連する無次元量を次に示す．

$$
\begin{aligned}
& \boldsymbol{r}_{i}=Q_{0} \boldsymbol{r}_{i}^{*}, \quad Q=Q_{0} Q^{*}, \quad t=\lambda_{0} t^{*}, \\
& \boldsymbol{\kappa}=\boldsymbol{\kappa}^{*} / \lambda_{0}, \quad \dot{\boldsymbol{\varepsilon}}=\dot{\boldsymbol{\varepsilon}}^{*} / \lambda_{0}, \\
& \boldsymbol{\sigma}=n k_{B} T \boldsymbol{\sigma}^{*}, \quad \bar{\eta}=n k_{B} T \lambda_{0} \bar{\eta}^{*}, \\
& b=\frac{H Q_{0}^{2}}{k_{B} T}, \quad a=\frac{\lambda_{H}}{\lambda_{0}}
\end{aligned}
$$

ただし， $\lambda_{0}$ はdumbbellの基準となる緩和時間， $\lambda_{H}=\zeta / 4 H$ は 個々のdumbbellの緩和時間である .ここで, FENE dumbbell

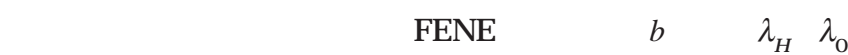
の比で定義される緩和時間パラメータ $\alpha$ 導入した . bあるい は $\alpha を$ 分布させてレオロジー特性の計算を行うことにより dumbbellの最大伸長長さの分布および緩和時間の分布の影響 を調べる .

FENEパラメータbおよび緩和時間パラメータ $\alpha$ の分布は， 前報で示したようにこれらの值の10を底とした対数值が正規 分布するように定めた . なお, 計算は前報と同じくT able Iに 示す5つの条件で行った .

Table I Parameter conditions for BD simulations.

\begin{tabular}{|c|c|c|c|c|}
\hline Condition & FENE parameter $b$ & Relaxation time parameter $\alpha$ & Average & Variance \\
\hline A & distribution & 1.00 & $\begin{array}{c}\langle b\rangle=192 \\
(\langle\log b\rangle=2)\end{array}$ & 0.5 \\
\hline B & 100 & distribution & $\begin{array}{c}\langle\boldsymbol{\alpha}\rangle=1.92 \\
(\langle\log \alpha\rangle=0)\end{array}$ & 0.5 \\
\hline C & 192 & 1.00 & - & - \\
\hline D & 100 & 1.92 & - & - \\
\hline E & 100 & 1.00 & - & - \\
\hline
\end{tabular}

\section{3. 単純伸長流れ特性}

Fig.1に示すように $x$ 方向を流れ方向とする単純伸長流れに おいて , 速度勾配テンソル ${ }^{*}$ は次式のようになる。

$$
\boldsymbol{\kappa}^{*}=\dot{\varepsilon}^{*}\left[\begin{array}{ccc}
1 & 0 & 0 \\
0 & -1 / 2 & 0 \\
0 & 0 & -1 / 2
\end{array}\right]
$$

\section{ここで， $\dot{\varepsilon}^{*}$ は伸長速度である．}

単純伸長流れ特性は, 伸長粘度, dumbbellの長さおよび配 向で示すことにする．また， dumbbellの3次元配向は，Fig.1 に示すように $x y$ 面,$y z$ 面,$z x$ 面への正投影を基にして配向楕 円を用いて表す．なお，配向は $x$ 方向に対して軸対称になる ので, $x y$ 面と $y z$ 面の配向楕円で表すことにする . 伸長粘度 $\bar{\eta}^{*}$ は次式により求められる.

$$
\bar{\eta}^{*}=\frac{\sigma_{x x}{ }^{*}-\sigma_{y y}{ }^{*}}{\dot{\varepsilon}^{*}}
$$

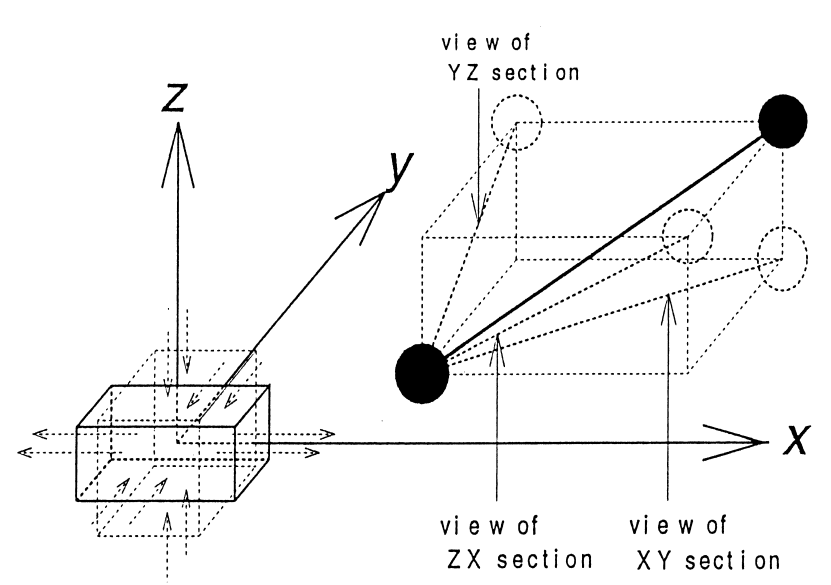

Fig.1 Coordinate system in a uniaxial extensional flow. 


\section{1 定常 特性}

ここでは, FENEパラメータの分布と緩和時間パラメータ の分布が定常特性に及ぼす影響について示す.計算に用いた dumbbellの個数はパラメータが分布している場合 (condition A, B ) は $m=2400$, 一定の場合 (condition C, D, E) は $m=300$ である．また，十分に定常になった後，0.01時間毎の100点に ついて時間平均をとった .このような計算を100回行い, 光 の平均値と標準偏差 (誤差棒) を計算結果に示した.

伸長粘度, dumbbellの長さの2乗平均のルートについて, $b$ および $\alpha$ が分布している場合の結果を乥れ光れFig.2, Fig.3に 示す. 比較のために $b$ おび $\alpha$ が分布していない場合， $b=10,100,1000(\alpha=1)$ の結果と， $\alpha=0.1,1,10$ ( $b=100)$ の結果 をFig.4 , Fig.5に示す.また , dumbbellの配向状態をFig.6に 示す。

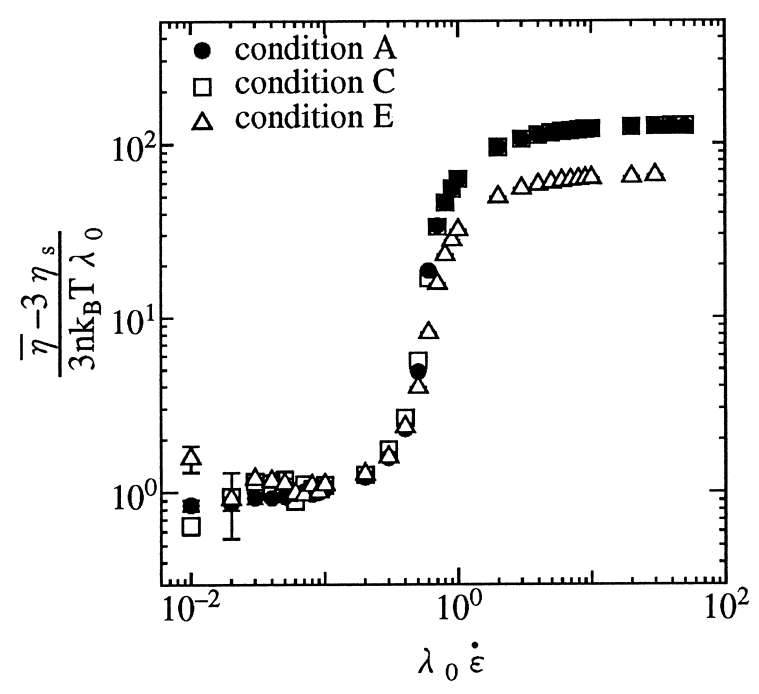

(a) Extensional viscosity

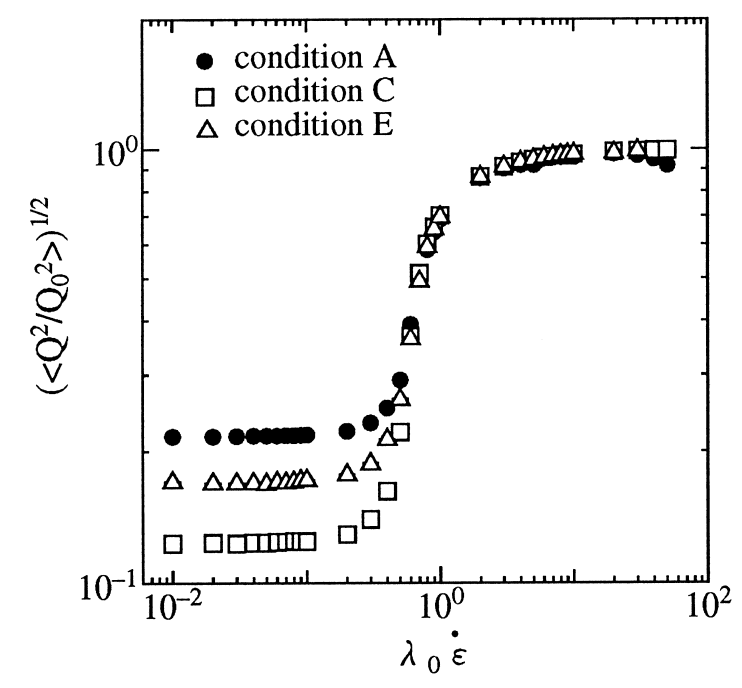

(b) Root-mean-square of dumbbell length

Fig.2 Effect of the distribution of FENE parameter in a steady extensional flow.
Fig.2(a) , Fig.3(a) からFENE dumbbellモデルでは , パラ メータが分布している場合にも伸長速度の増加に伴い伸長粘 度は増大し, stretch thickening性を示すことが分かる.更に， FENE springの有限伸長性により，伸長速度の増加に伴い伸 長粘度はある值に漸近している．Birdら ${ }^{2)}$ によると低伸長速 度と高伸長速度の極限において, 伸長粘度は光れ光れ次のよ うになることが示されている。

$$
\begin{aligned}
& \lambda_{0} \dot{\varepsilon} \rightarrow 0 ; \quad \frac{\bar{\eta}-3 \eta_{\mathrm{s}}}{3 \mathrm{nk}_{\mathrm{B}} \mathrm{T} \lambda_{0}}=\frac{\mathrm{b}}{\mathrm{b}+5} \\
& \lambda_{0} \dot{\varepsilon} \rightarrow \infty ; \quad \frac{\bar{\eta}-3 \eta_{\mathrm{s}}}{3 \mathrm{nk}_{\mathrm{B}} \mathrm{T} \lambda_{0}}=\frac{2 \mathrm{~b}}{3}
\end{aligned}
$$

次に分布の影響について示すと, bが分布している場合に は，伸長粘度にはほとんど分布による影響が見られない .こ れに対して， $\alpha$ 分布している場合には, 分布している方が より小さい伸長速度からstretch thickening性が現れ始める。

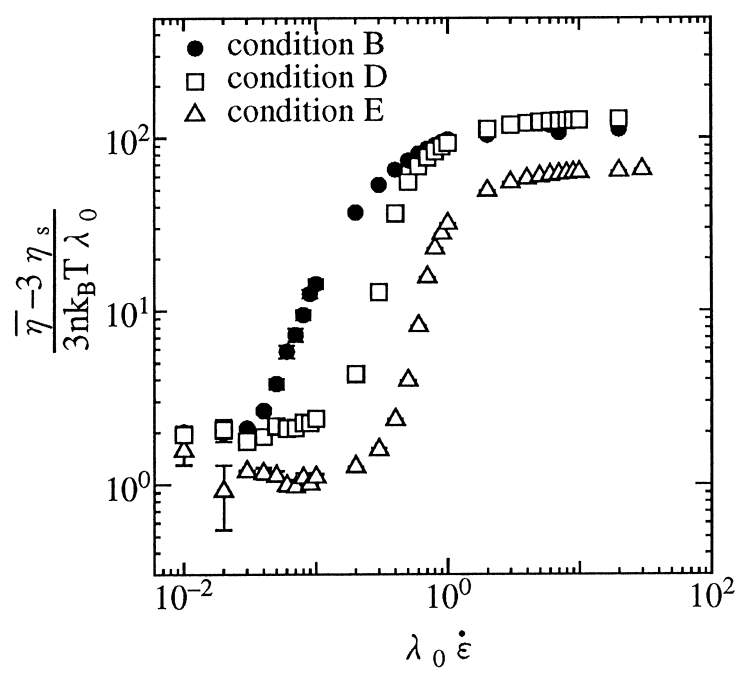

(a) Extensional viscosity

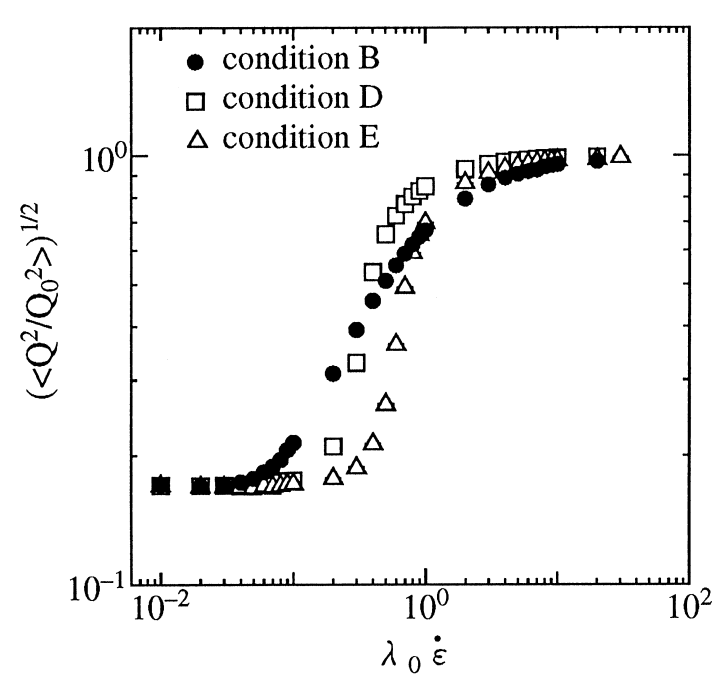

(b) Root-mean-square of dumbbell length

Fig.3 Effect of the distribution of relaxation time parameter in a steady extensional flow. 


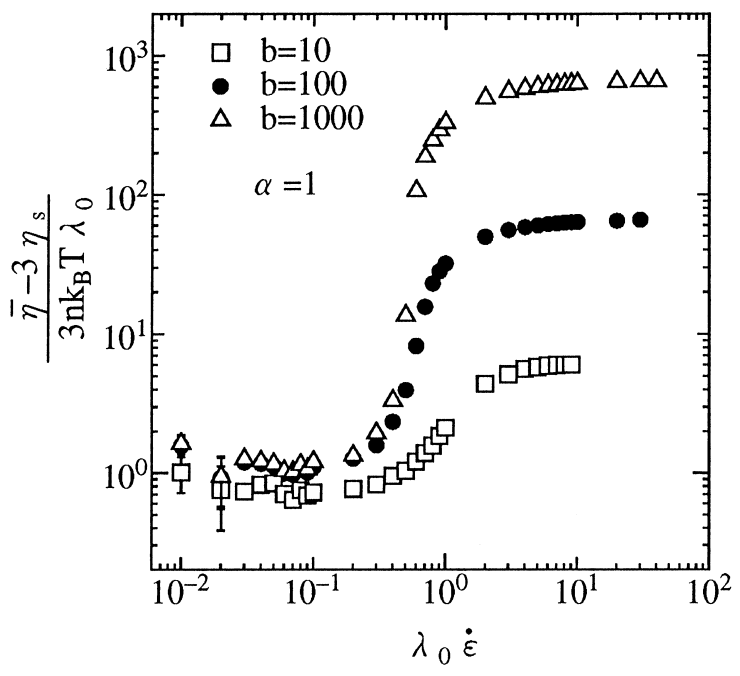

(a) Extensional viscosity

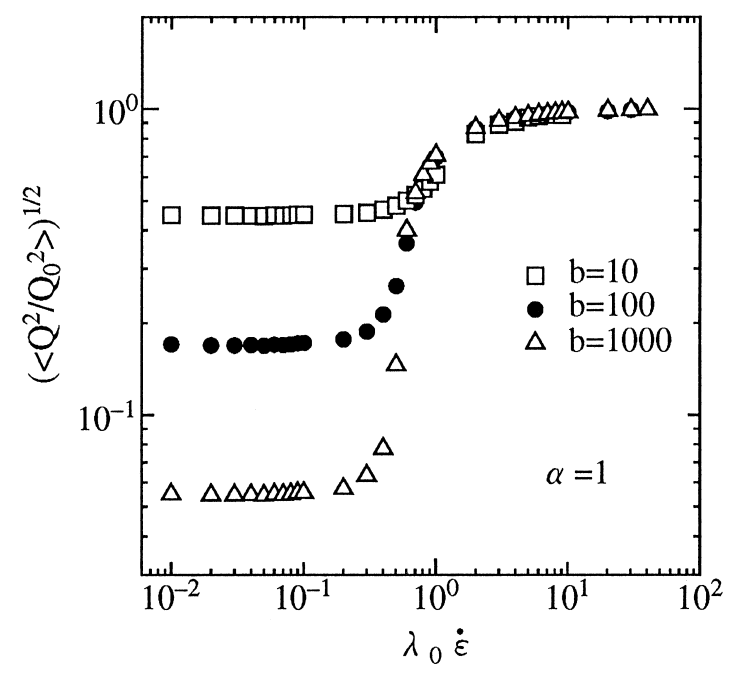

(b) Root-mean-square of dumbbell length

Fig.4 Steady extensional properties for FENE parameters $b=10,100$ and 1000 .

また , 分布している方がなだらかに最大值に漸近している このような伸長粘度の変化は, Fig.3(b) のcondition Bと condition Dの結果を比較すると， $\alpha$ 分布していない condition Dの場合にはdumbbellの長さは急激に変化している が , condition Bの場合にはなだらかに最大值に漸近している ことからも推定できる.更に，Fig.5から，小さい伸長速度か らstretch thickening性か現れるのは緩和時間の大きい分子に よる影響であり，なだらかに最大值に漸近するのは緩和時間 の小さい分子による影響であることが分かる .

なお，単分散系では，伸長粘度ならびに伸長速度の無次元 化の方法からFig.5(a) の伸長粘度の場合には $\alpha$ の值の大きい曲 線を右下の方向に平行移動すれば $\alpha の$ 值の小さい曲線に重な ることが分かる . また , Fig.5(b) のdumbbellの長さについて は横軸に平行に移動すれば重なる . 単分散系における緩和時 間の効果はこのような平行移動で得られることになる．これ は, Fig.3のcondition DとEについても当然成り立つ．

dumbbellの配向については, Fig.6において一軸伸長流れで
あるため配向の主方向は常に流れ方向であり，伸長速度の増 加に伴い配向の程度が良好になる。

前報で述べたように，せん断流れの場合には，下流側に位 置するbeadの速度が上流側のbeadの速度より小さくなるとき がありflip-overが生ずる．しかし，伸長流れでは，Fig.7に示 すようにブラウン運動によりdumbbellは摇らいでいるが，常 に下流側のbeadの速度が大きくなるのでdumbbellには溶媒か ら伸長力が作用する．このためdumbbellはflip-overを起こさ ず流れ方向に良好に配向する。

なお，前報においてせん断速度が非常に小さい領域 $\left(\lambda_{0} Y<0.1\right)$ ではブラウン運動が支配的になるためにせん断 レオロジー特性に大きなばらつきが生じた .これに対して， Figs.2〜5において伸長速度の非常に小さい領域でも，伸長粘 度はほとんどばらついていない，これは，上述したように流 動樣式が異なることに起因するdumbbellの運動の違いによる と考えられる .

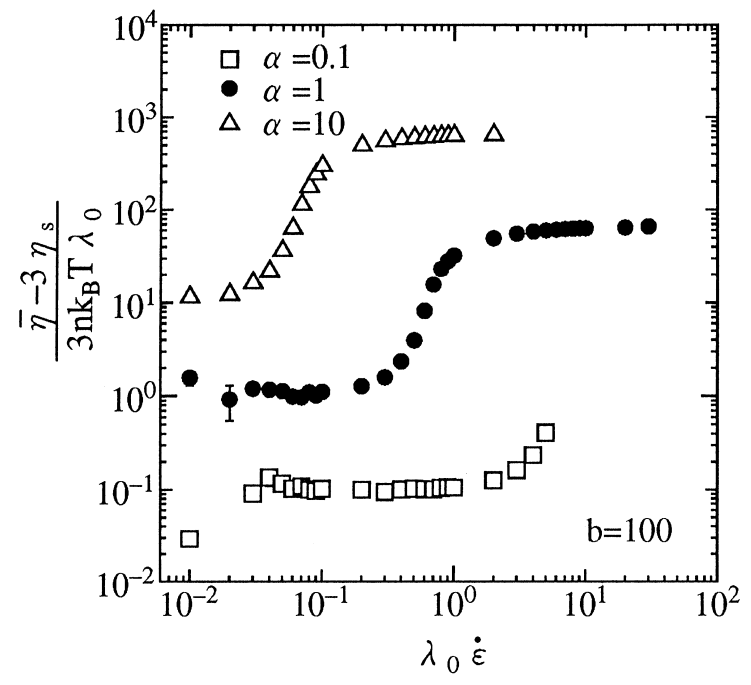

(a) Extensional viscosity

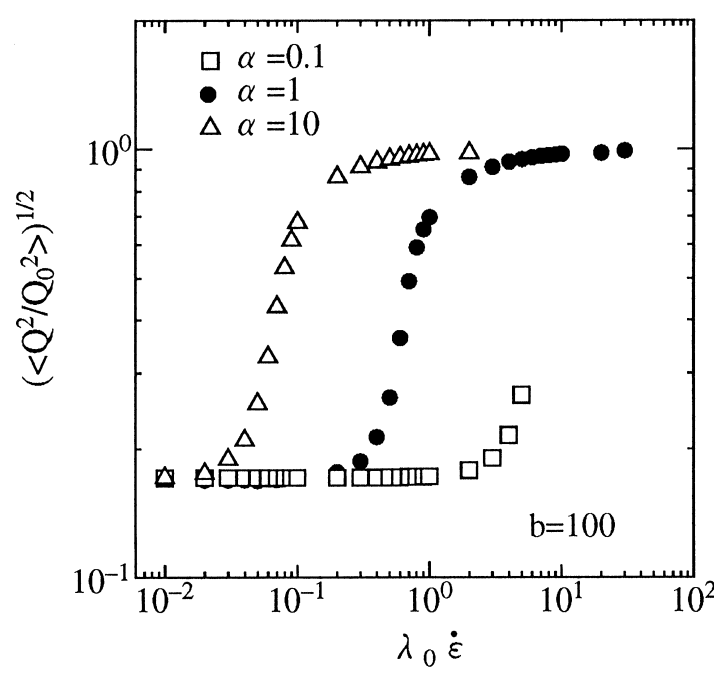

(b) Root-mean-square of dumbbell length

Fig.5 Steady extensional properties for relaxation time parameters $\alpha=$ $0.1,1$ and 10 . 


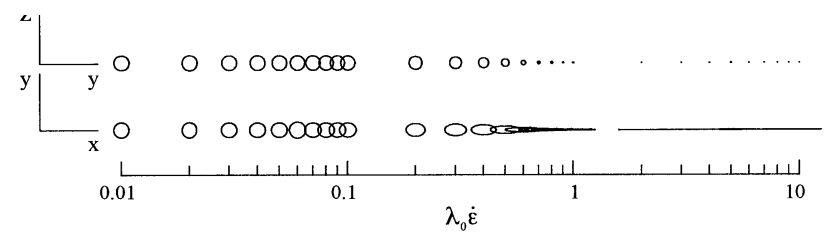

(a) Condition A

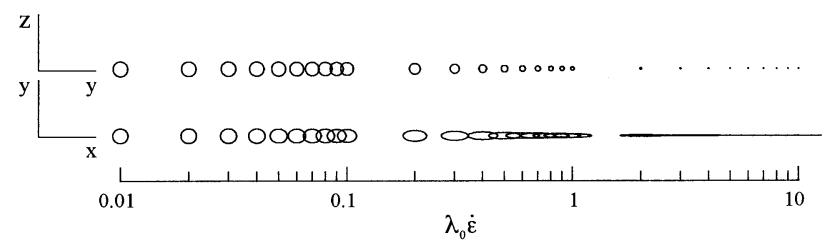

(b) Condition B

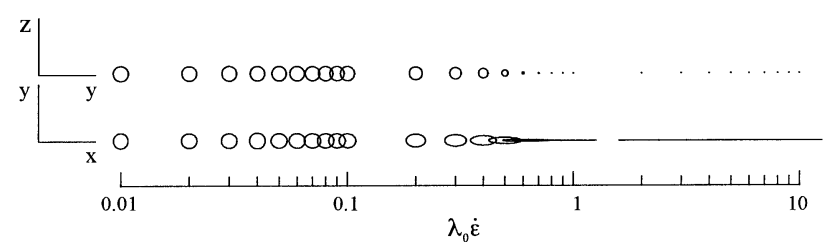

(c) Condition C

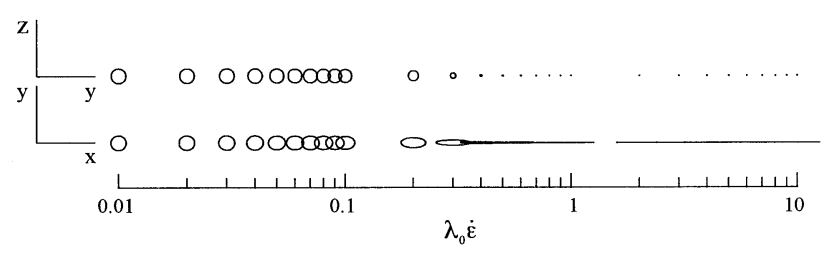

(d) Condition D

Fig.6 Variation of dumbbell orientation with stretch rate for conditions $\mathrm{A}, \mathrm{B}, \mathrm{C}$ and D.

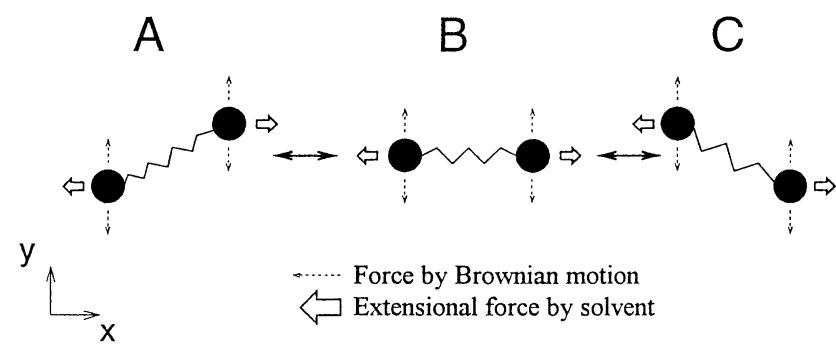

Fig.7 Orientation of dumbbell in an extensional flow.

\section{2 スタートアップ流動特性}

dumbbellの個数はパラメータが分布している場合 (condition A, B) には $m=5000$, 一定の場合 (condition C, D)

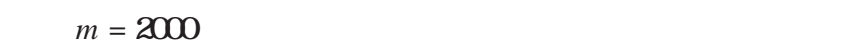
ている場合には30回, 一定の場合には20回行い, 弚の平均値 と標準偏差 (誤差棒) を計算結果に示した。

伸長粘度, dumbbellの長さの2乗平均のルートについて, $b$

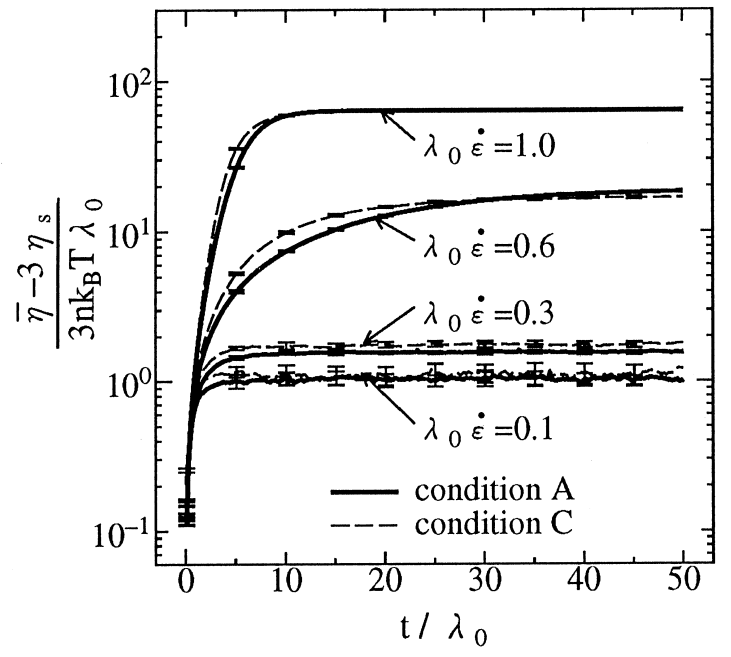

(a) Extensional viscosity

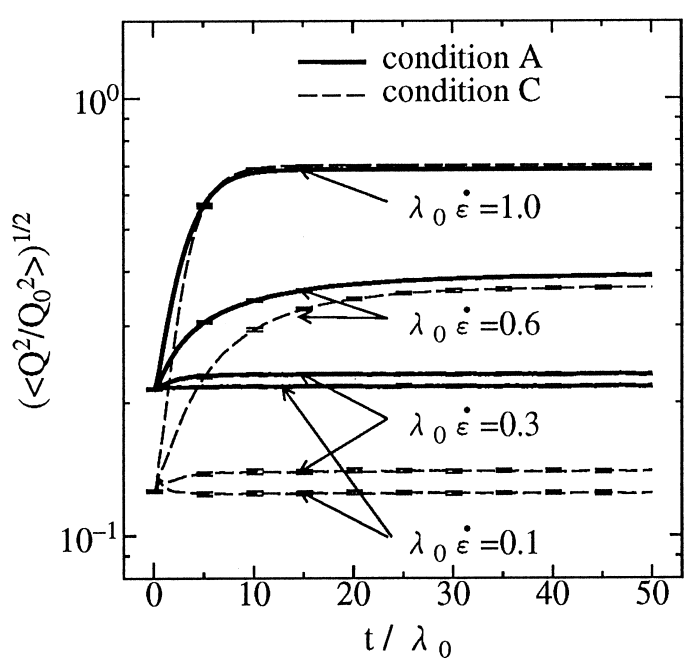

(b) Root-mean-square of dumbbell length

Fig.8 Effect of the distribution of FENE parameter in a start-up extensional flow, at $\lambda_{0} \dot{\varepsilon}=0.1,0.3,0.6$ and 1.0 , for conditions A and $\mathrm{C}$.

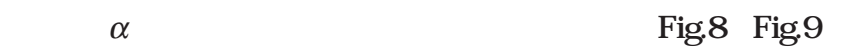
示す. また, 比較のためにパラメータが分布していない場合, $b=10,100,1000\left(\alpha=1, \lambda_{0} \dot{\varepsilon}=0.6\right) \quad$ と $\alpha=0.1,1,10(b=100$, $\left.\lambda_{0} \dot{\varepsilon}=0.1\right)$ の伸長粘度の結果をFig.10に示す．

$b$ あいはが $\alpha$ 分布している場合にも，分布していない場 合にも，伸長流れのスタートアップ流動特性には，せん断流 れの場合に見られたovershoot 現象は見られなかった .この 現象は，TirtaatmadjaとSridhar ${ }^{12)}$ がfilament stretching rheometerを用いて行った高分子溶液の伸長粘度測定におい ても観察されなかった .

この原因は, せん断流れと伸長流れでdumbbellが溶媒から 受ける力が異なるためである . 平衡状態のdumbbellが突然大 きなせん断流れにさらされると，下流側に位置するbeadと上 


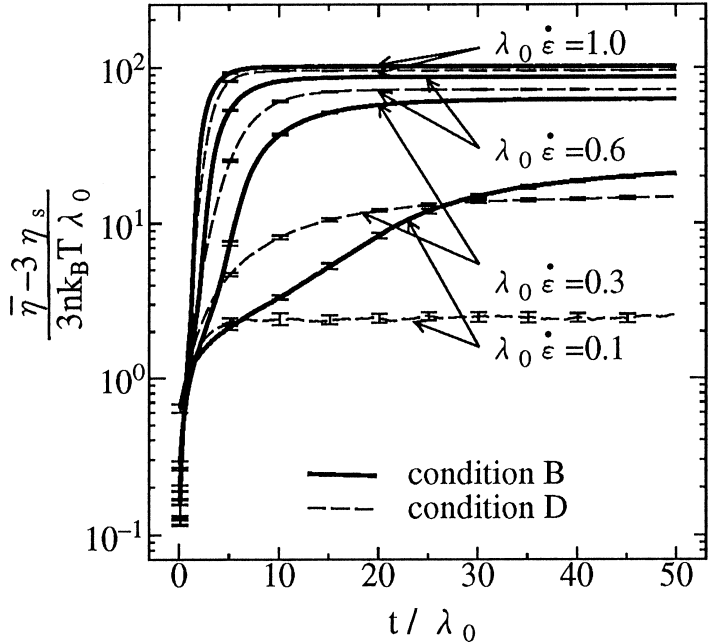

(a) Extensional viscosity

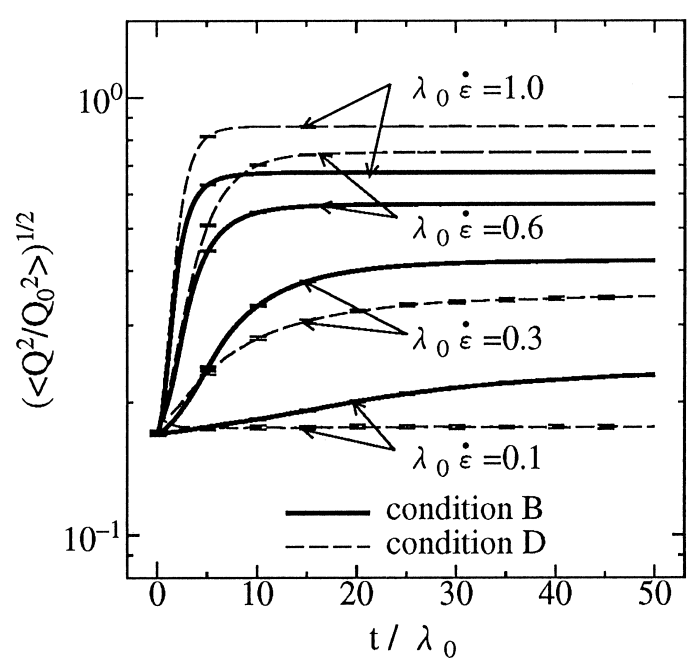

(b) Root-mean-square of dumbbell length

Fig.9 Effect of the distribution of relaxation time parameter in a startup extensional flow, at $\lambda_{0} \dot{\varepsilon}=0.1,0.3,0.6$ and 1.0 , for conditions $\mathrm{B}$ and $\mathrm{D}$.

流側に位置するbeadの速度差によりdumbbellは急激に伸ばさ れ，流れ方向に配向していく．ところが，dumbbellの配向方 向が流れ方向に近づくと, 二つのbeadsの速度差は減少して いくためdumbbellが容媒から受ける力は小さくなる .これに 対して , 伸びた状態にあるFENE springには大きな復元力が 働いている．従って，急激に伸ばされたdumbbellが急激に縮 むことになるので, せん断流れではレオロジー特性ならびに dumbbell の長さにovershoot現象が見られる .

一方，平衡状態のdumbbellに突然大きな伸長をかけると， dumbbellは溶媒からの伸長力により急激に伸ばされ，流れ方 向に配向していくが, dumbbellが伸びれば伸びるほど dumbbellに働く溶媒からの伸長力も大きくなる .このため， dumbbellはFENE springの復元力と溶媒からの伸長力が釣り

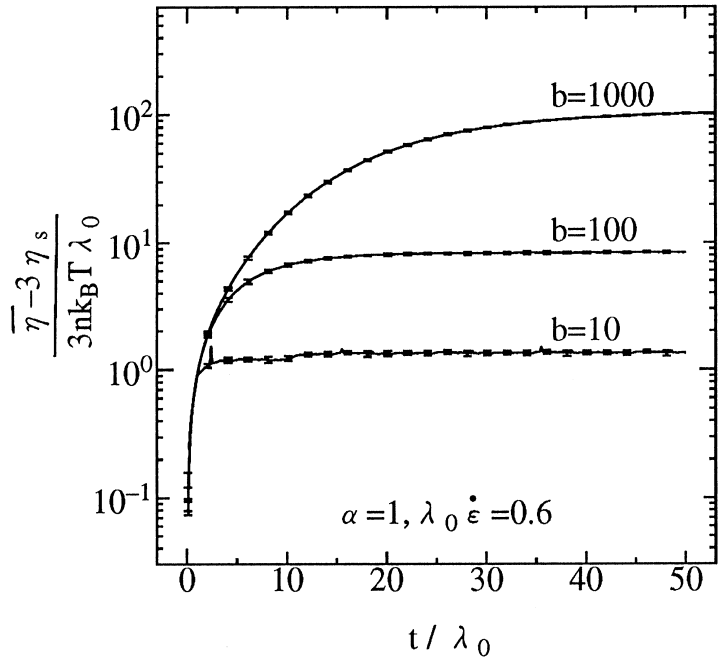

(a) FENE parameters $b=10,100$ and 1000

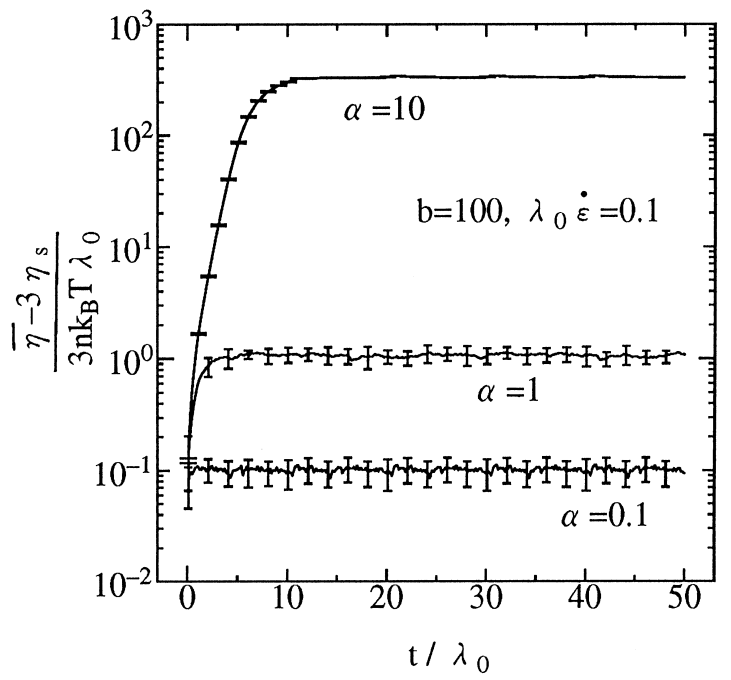

(b) Relaxation time parameters $\alpha=0.1,1$ and 10

Fig.10 Time evolution of the start-up extensional viscosity for (a) $\alpha=1$, $\lambda_{0} \dot{\varepsilon}=0.6, b=10,100$ and 1000 ; (b) $b=100, \lambda_{0} \dot{\varepsilon}=0.1, \alpha=0.1$, 1 and 10 .

合うまで伸びることになる . 従って , 伸長流れではovershoot 挙動を示さない .

また，Fig.11からdumbbellは時間の経過とともにランダム な配向状態から流机方向に配向していき，定常状態に達する ことが分かる .

次に分布による影響について示す. $b$ が分布している場合 には $\lambda_{0} \dot{\varepsilon}=0.6 の と き に$ 分布している方が伸長粘度が定常值に 達するのに長い時間を要している . Fig.1O(a)より，これは $b$ の大きい dumbbellの影響であると考えられる .このように中 程度の伸長速度でbの分布の影響が現れた原因として次のよ うに考えられる.伸長速度が小さい領域では，定常伸長長さ は小さく，全てのdumbbellか短時間のうち $\left(t / \lambda_{0} \approx 5\right)$ に定常 值に到達できる．また，伸長速度が大きい領域では，伸長力 
が大きくなるため, どのdumbbellも短時間のうち $\left(t / \lambda_{0} \approx 10\right)$ に最大長に近い状態になるので分布の影響が見られない . 従って , 中程度の伸長速度で伸長粘度に及ぼすの分布の影響 が最も顕著に現れる。

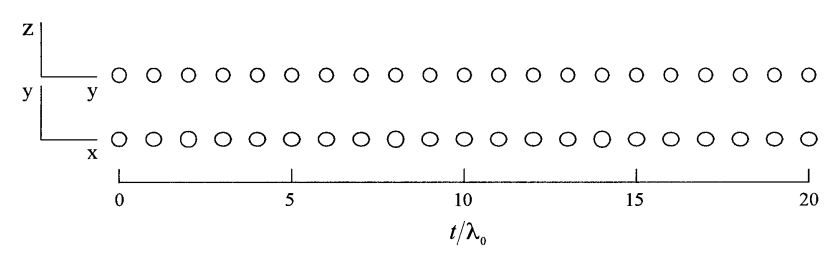

(a) $\lambda_{0} \dot{\varepsilon}=0.1$

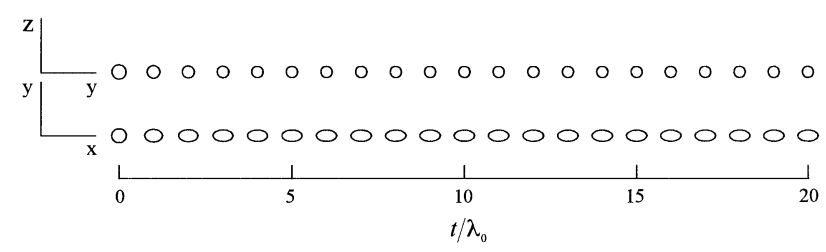

(b) $\lambda_{0} \dot{\varepsilon}=0.3$

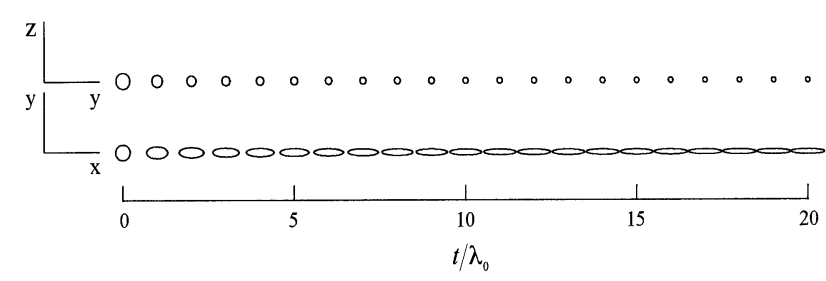

(c) $\lambda_{0} \dot{\varepsilon}=0.6$

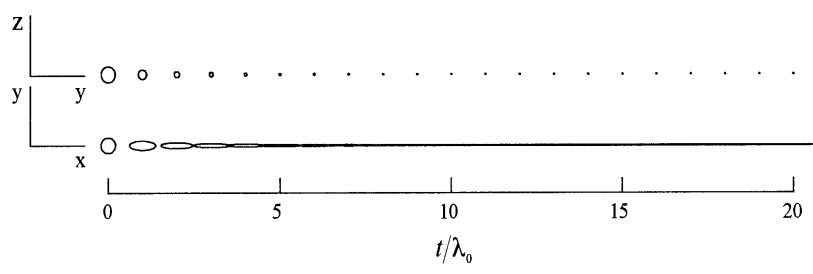

(d) $\lambda_{0} \dot{\varepsilon}=1.0$

Fig.11 Time evolution of the orientation ellipse of dumbbell in a start-up extensional flow, at $\lambda_{0} \dot{\varepsilon}=0.1,0.3,0.6$ and 1.0 , for condition A.

一方， $\alpha$ が分布している場合には, 伸長速度が小さいほど 伸長粘度に分布の影響か湿著に現れるが, $\lambda_{0} \dot{\varepsilon}=1.0 に$ 近づく とほとんど見られなくなる .これは緩和時間の大きい分子の 影響であると考えられる (Fig.10(b) 参照, $\alpha$ が大きいほど伸 長粘度の成長速度が大きくなる) . また , 伸長速度が大きく なるにつれて分布の影響が小さくなるの, dumbbellが短時 間のうちに最大長に近い状態になるからである．また，伸長 粘度およびdumbbellの長さともに伸長速度が小さいほど定常 状態になるのに長い時間を要することも分かる . しかし，ここで用いた分布条件の場合には，bの分布が過 渡的伸長粘度に及ぼす影響は $\alpha$ 分布の影響に比べてほとん ど無視できる程度である．

これまでは伸長粘度の時間に対する発達状態について考察 し, FENE dumbbellの希薄懸濁液はstrain-hardening性を呈す ることが分かった . strain-hardening挙動は溶液中での分子の 配向と伸長に起因し， $\lambda_{H} \dot{\varepsilon}=1$ を越えると顕著になることが分 子のcoil-stretch transitionの議論から明らかにされてい る ${ }^{19), 20)}$. 更に , TirtaatmadjaとSridhar ${ }^{12)}$ がfilament stretching rheometerによる伸長粘度測定で得た結果，即ち，顕著な strain-hardeningの領域では伸長ひずみ $\varepsilon=\dot{\varepsilon} t$ と過渡的伸長粘 度の関係が伸長速度に関係なく一致する傾向にあることが示 されており，ここでもこの傾向が見いだされるかどうか調べ る.Fig.12にcondition Aとcondition Bの $\lambda_{0} \dot{\varepsilon}=0.6,1.00$ 結果を 示す . 測定では , 溶液の種類にもよるが $\varepsilon \approx 6$ 程度で定常值に

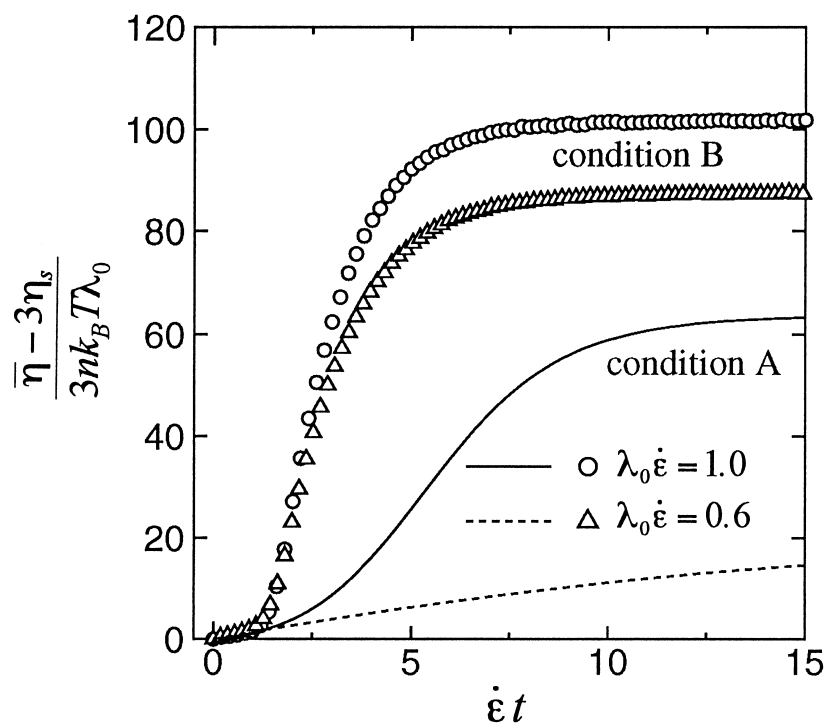

Fig.12 Transient viscosity against strain in a start-up extensional flow, at $\lambda_{0} \dot{\varepsilon}=0.6$ and 1.0 , for conditions $\mathrm{A}$ and $\mathrm{B}$.

達している .これに比べて本研究では, 大きな緩和時間を有 するcondition Bの場合には比較的小さいひずみで定常状態に 達しているが，緩和時間の小さいcondition Aの場合には定常 值に達するのに必要なひずみが極めて大きいことが分かる． また，ここで用いた計算条件の範囲内ではcondition Bの場合 には，測定に見られるような伸長速度に関わらず過渡的伸長 粘度が伸長ひずみの関数として表されるという傾向が見られ るが, condition Aの場合にはほとんど見られない . condition Bの場合 $\langle\alpha\rangle=1.92 て ゙$ 緩和時間の平均値がcondition Aの場合 の2倍程度あるため, 同じ伸長速度で比べるとcondition Bの 方がstrain-hardening性が顕著となる . しかも, condition Aの 場合 $\langle b\rangle=192$ と大きためdumbbellが十分に伸長されるの に要する時間が長い.これもcondition Aの場合 strainhardening性か湿著に現れにくい原因となっている．

Figs.2(a)，3(a) から伸長速度と定常伸長粘度の関係は次の3 つの領域に分割できる．すなわち， $\alpha \lambda_{0} \dot{\varepsilon}>0.2 \sim 0.3 の$ 領域は 二ュートン流体の性質か現れる線形領域， 0.2 0.3< $\alpha \lambda_{0} \dot{\varepsilon}<$ 
1〜2の領域は急激に粘度が増大する遷移領域， $\alpha \lambda_{0} \dot{\varepsilon}>1 \sim 2$ の領域は伸長粘度が飽和して一定となる領域である. 光して， 第3の領域において定常状態になるまで伸長すると， dumbbellはほぼ最大長まで伸びしかも流れ方向に配列するこ とが分かる (Figs.2(b)，3(b)，Fig.6参照). 更に，この第3の 領域ではstrain-hardening挙動か湿著に現れ（Figs.8(a)，9(a) 参照)，伸長ひずみと過渡的伸長粘度の関係が伸長速度に関 係なく一つのマスターカーブで表される．Fig.12に示す condition Aの条件は，第2の遷移領域に属するためマスター カーブに重ならないことになる．また，condition Bの場合で もFig.9(a) に示す $\lambda_{0} \dot{\varepsilon}=0.1,0.3$ 条件ではマスターカーブか ら外れることか確かめられている. 従って, condition Aの場 合でも伸長速度を大きくして $\alpha \lambda_{0} \dot{\varepsilon}>1 \sim 2 の$ 条件で計算すれ ば当然マスターカーブが得られる。

\section{4. ま と め}

希薄高分子溶液を FENE dumbbellの希薄懸濁液でモデル化 し，BD simulationにより伸長流動特性に及ぼすdumbbellの最 大伸長長さ (FENEパラメータ) の分布と緩和時間の分布の 影響について調べた。

FENEパラメータや緩和時間が分布している場合でも，一 般に高分子溶液で観察される特徵であるstretch-thickening性 (定常特性) およびstrain-hardening挙動（過渡特性）などを 確認することができた .

伸長流動特性に及ぼすパラメータの分布の影響は以下の通 りである。

（1）定常特性：伸長粘度にはFENEパラメータの分布の影響 がほとんど見られない．これに対して，緩和時間が分 布している場合には，一定の場合と比べてより小さい 伸長速度からstretch thickening性か現れ始め，また，ゆ っくり最大值に近づく.

（2）スタートアップ流動特性 : FENEパラメータあるいは緩 和時間が一定の場合にも，分布している場合にも，伸 長流れのスタートアップ流動特性には, せん断流れの 場合に見られたovershoot現象は見られなかった .この overshoot現象は, TirtaatmadjaとSridhar ${ }^{12)}$ がfilament stretching rheometerを用いて行った高分子溶液の伸長 粘度測定においても観察されていない，また，緩和時 間が分布している場合には, 伸長速度が小さいほど伸 長粘度に分布の影響か顕著に現れるが, 伸長速度の増 加に伴いほとんど見られなくなる，一方， dumbbellは 時間の経過とともにランダムな配向状態から流れ方向 に配向し定常状態に達する。

(3) 伸長ひずみと過渡的伸長粘度の関係 : 定常状態まで伸 長するときdumbbellがほぼ最大長まで伸びしかも流れ 方向に配列する条件 $\left(\alpha \lambda_{0} \dot{\varepsilon}>1 \sim 2\right)$ では, strainhardening性か湿著となり，伸長ひずみと過渡的伸長粘 度の関係が伸長速度に関わらずほぼ一つのマスター
カーブで表される．従って，ゆっくり伸長しても急速 に伸長しても，同一の伸長ひずみで生じる伸長粘度の 值は同じである

従って，ここで用いたような分布の場合には，伸長流 動特性に及ぼすFENEパラメータの分布の影響はほとん ど見られないが，緩和時間の分布は定常特性ならびに 過渡特性に影響を及ぼすことが明らかになった。なお， 前報でせん断速度の小さい領域 $\left(\lambda_{0} Y<0.1\right)$ ではせん 断特性に大きなばらつきが見られた。しかし，伸長粘 度は，伸長速度の非常に小さい領域でもほとんどばら ついていない。

\section{参考文献}

1）千葉訓司，寺岡寛二，五百旗頭祐二，中村喜代治，日 本レオロジー学会誌, 27,31 (1999).

2) Bird RB, Curtiss CF, Armstrong RC, Hassager O, "Dynamics of Polymeric Liquids: Kinetic Theory",

Vol.2, 2nd ed. (1987), John Wiley and Sons, New York.

3) Warner HR, Ind Eng Chem Fundam, 11, 379 (1972).

4) Bird RB, Dotson PJ, Johnson NL, J Non-Newtonian Fluid Mech, 7, 213(1980).

5) Peterlin AJ, J Polym Sci, Polym Lett, 4B, 287 (1966).

6) Wedgewood LE, Ostrov DN, Bird RB, J Non-Newtonian Fluid Mech, 40, 119 (1991).

7) van den Brule BHAA, J Non-Newtonian Fluid Mech, 47, 357 (1993).

8) Fetsko SW, Cummings PT, J Rheol, 39, 285 (1995).

9) Herrchen M, Öttinger HC, J Non-Newtonian Fluid Mech, 68, 17 (1997).

10) Chilcott MD, Rallison JM, J Non-Newtonian Fluid Mech, 29, 381 (1988).

11) Sridhar $T$, Tirtaatmadja $V$, Nguyen DA, Gupta RK, J NonNewtonian Fluid Mech, 40, 271 (1991).

12) Tirtaatmadja V, Sridhar T, J Rheol, 37, 1081 (1993).

13) Spiegelberg SH, Ables DC, McKinley GH, J Non-Newtonian Fluid Mech, 64, 229 (1996).

14) Spiegelberg SH, McKinley GH, J Non-Newtonian Fluid Mech, 67, 49 (1996)

15) van Nieuwkoop J, Muller von Czernicki MMO, J NonNewtonian Fluid Mech, 67, 105 (1996).

16) Sizaire R, Legat V, J Non-Newtonian Fluid Mech, 71, 89 (1997).

17) Kolte MI, Rasmussen HK, Hassager O, Rheol Acta, 36, 285 (1997).

18) Yao M, McKinley GH, J Non-Newtonian Fluid Mech, 74, 47 (1998).

19) DeGennes PG, J Chem Phys, 60, 5030 (1974).

20) Hinch EJ, Phys Fluids, 20, S22 (1977) 